\title{
Alemanha: o modelo de capitalismo social e os desafios no limiar do século XXI
}

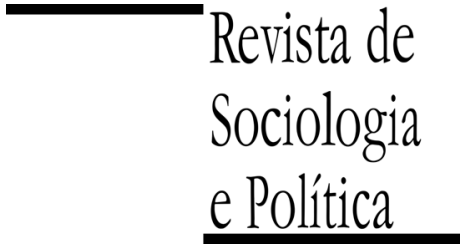

DOI 10.1590/1678-987314225104

\author{
Alexandre Queiroz Guimarães, Flavio Constantino \\ Barbosa, Guilherme Ottoni Costa, Enrique Natalino, \\ Paulino Oliveira Neto
}

\section{RESUMO}

A Alemanha consolidou ao longo do século XX um modelo de capitalismo diferente, marcado por uma estrutura de governança corporativa baseada nos stakeholders, pela presença de relações de trabalho participativas, com grande papel conferido aos trabalhadores, e pela existência de uma fonte de capital paciente, resultado das relações desenvolvidas entre bancos e empresas. Essas características ajudam a explicar, entre outros fatores, as fontes de vantagem comparativa, o padrão de inovação e as baixas diferenças salariais. No entanto, esse modelo passou a sofrer pressões com as mudanças verificadas no capitalismo a partir da década de 1970. O artigo avalia a evolução do modelo alemão em resposta a esses desafios. Um ponto central é verificar como as instituições têm evoluído e destacar em que sentido a Alemanha ainda tem um modelo de capitalismo diferente. Outro ponto é entender os desafios enfrentados em termos de produtividade e competitividade, relacionando-os com as características institucionais, com o contexto externo e com a estratégia internacional do país. O artigo utiliza a abordagem do institucionalismo histórico e dos modelos de capitalismo, paradigmas que exploram as características institucionais dos países e a sua persistência ao longo do tempo. Centrou-se em fontes bibliográficas, em artigos da mídia especializada e em bases de dados que dialogam com os aspectos institucionais da economia alemã. Como principais resultados, encontrou-se que o modelo alemão vem se transformando, mas que importantes traços institucionais têm sido preservados, desempenhando papel essencial para o sucesso da economia alemã. Os resultados indicam que um tipo diferente de capitalismo, mais participativo, é possível, a despeito das transformações na esfera internacional. O artigo destaca também a relevância das práticas participativas e da cooperação dos trabalhadores para os resultados alcançados. São conclusões que iluminam também os desafios que precisam ser enfrentados pela economia alemã.

PALAVRAS-CHAVE:Alemanha; institucionalismo histórico; modelos de capitalismo; instituições; economia política.

Recebido em 10 de Fevereiro de 2012. Aprovado em 9 de Setembro de 2013.

\section{I - Introdução ${ }^{1}$}

\footnotetext{
1 Os autores agradecem ao Fundo de Incentivo à Pesquisa da Pontifícia Universidade Católica de Minas Gerais (PUC Minas) pelo financiamento concedido, bem como aos pareceristas anônimos da Revista de Sociologia e Política pelos comentários feitos ao presente artigo.
}

\begin{abstract}
A Alemanha consolidou, no século XX, um modelo de capitalismo bem particular, cujas origens remontam ao século XIX e à necessidade de buscar apoio político em um contexto não democrático. Após a II Guerra Mundial, o modelo assumiu sua forma mais inclusiva, com a existência de canais institucionalizados de participação dos trabalhadores e com a consolidação de um abrangente Estado de Bem-Estar Social. Entre os resultados alcançados, a então República Federal Alemã destacou-se pela capacidade de conquistar mercados internacionais em setores industriais mais elaborados e pelo grau mais igualitário de seu capitalismo. Vários aspectos institucionais contribuíram para esses resultados, incluindo a qualidade das instituições de treinamento e os canais de participação, que fortaleciam o comprometimento dos trabalhadores com os objetivos das firmas, e a existência de um capital mais paciente, fruto da relação entre os bancos e as empresas.
\end{abstract}

Os bons resultados do modelo foram colocados em xeque a partir dos anos 1970, fruto de dificuldades gerais do capitalismo e também de dificuldades 
institucionais do modelo alemão. As empresas alemãs mostraram-se lentas em introduzir novas técnicas produtivas, perdendo competitividade. A isso somaram-se, posteriormente, outros desafios, que incluíram os impactos da unificação alemã e do fim do comunismo no Leste europeu. Como resultado, o modelo alemão viu-se na defensiva, enfrentando críticas que defendiam a necessidade de reformas na direção de um capitalismo mais liberal. Não obstante, os alemães recusaram mudanças radicais; após décadas de paralisia, mudanças foram feitas na direção de ajustar o modelo e prepará-lo para o novo contexto, mas sem abrir mão de fatores distintivos do modelo socialmente coordenado.

O objetivo do presente artigo é avaliar as respostas e a evolução do modelo alemão a partir dos desafios que emergiram na década de 1970. Um ponto central é verificar como as instituições têm evoluído e destacar em que sentido a Alemanha ainda tem um modelo de capitalismo diferente. Outro ponto é entender os desafios que a Alemanha enfrenta e relacioná-los com as características institucionais. Como uma conclusão central, verifica-se que as engrenagens institucionais continuam muito ativas e desempenham papel essencial para os bons resultados que a economia alemã continua alcançando. A próxima seção faz uma síntese dos principais aspectos do modelo socialmente coordenado, desde as suas origens no século XIX até os constrangimentos que emergem na década de 1970. As principais implicações do quadro institucional são enfatizadas. A seção 3 faz uma sucinta avaliação das principais linhas que vêm, desde o pós-guerra, guiando a estratégia internacional do país. A seção 4 destaca as mudanças em termos de governança corporativa e da relação entre bancos e empresas, enquanto a seção 5 aborda como as relações de trabalho vêm evoluindo. A seção 6 avalia a situação recente da economia alemã, destacando os principais desafios em termos de inovação e competitividade. Enfim, a seção 7 esboça as considerações finais.

\section{II - As características institucionais do modelo socialmente coordenado}

As origens do modelo remontam ao século XIX, ao processo de modernização conservadora e à necessidade de buscar estabilidade e apoio político em um contexto em que os direitos políticos apenas engatinhavam. No âmbito nacional, alguns direitos sociais foram concedidos por Bismarck aos trabalhadores. Nas empresas, os trabalhadores ganharam conselhos e canais de participação, voltados a fortalecer a lealdade à empresa. Outro desdobramento do século XIX foi a resposta ao crescimento das empresas e à separação entre propriedade e controle. Diferentemente dos Estados Unidos, o fim do controle familiar foi seguido pela maior participação dos bancos e de outras empresas no controle da firma. Desenvolveu-se uma estrutura de ações cruzadas entre as empresas e os bancos, contribuindo para a maior concentração do capital. A proximidade entre os bancos e as empresas favoreceu a disponibilização de capital a riscos mais baixos, contribuindo para o alto grau de alavancagem das corporações alemãs (Streeck 2005).

Essas características iniciais mostraram-se decisivas, influenciando as escolhas posteriores que, por sua vez, acrescentaram novos traços a fortalecer as particularidades institucionais. Durante a I Guerra Mundial, os trabalhadores ganharam novas atribuições na rotina da empresa. Com a República de Weimar, novos arranjos fortaleceram os mecanismos de participação dos trabalhadores nas firmas. Muitas dessas práticas, abandonadas pelo governo nazista, foram resgatadas e fortalecidas no pós-guerra. Segundo Streeck (idem), o desenho institucional do pós guerra conferiu aos arranjos prévios traços mais democráticos, transformando os trabalhadores em parceiros e as concessões em direitos.

Naquele momento, havia a preocupação em apagar os traços do nazismo e fortalecer a legitimidade e o apoio social. Os canais de participação foram 
${ }^{2}$ Uma cultura diferente regia o modelo alemão, com a ideia de que os gerentes deveriam perseguir outros objetivos além do retorno financeiro do empreendimento (Streeck 1997).

${ }^{3}$ Práticas de treinamento e certificação haviam se desenvolvido bem cedo na Alemanha, contribuindo para a formação de trabalhadores em vários ofícios ligados à manufatura.

\footnotetext{
${ }^{4}$ Segundo Porter (1993), a Alemanha teria demonstrado liderança em 46 nichos da indústria de máquinas, contra 17 dos Estados Unidos. No setor serviços, a Alemanha
}

concedidos em troca do abandono de posições radicais. Assim, os trabalhadores assumiram atribuições tanto em nível empresarial como em nível nacional, participando, juntamente com os empresários, de negociações sobre ajustes salariais e desempenhando funções quase públicas. Na empresa, práticas de codeterminação davam aos trabalhadores assento nos conselhos diretores e paridade nas decisões relativas a salários e à contratação e demissão de pessoal. Apesar de ser um regime de mercado e das empresas serem movidas pelo lucro, as mesmas tinham responsabilidade com os stakeholders, principalmente os trabalhadores (Streeck 1997) ${ }^{2}$.

Esse arranjo trouxe diversas implicações. Por um lado, a participação dos trabalhadores limitava a autonomia do gerente e impedia práticas voltadas a aumentar a competitividade pela redução dos salários e dos direitos trabalhistas. Por outro lado, os trabalhadores eram parte da equipe, estando prontos para cooperar com práticas voltadas a aumentar a produtividade. Assim, o arranjo estimulava o engajamento tanto das empresas como dos trabalhadores em práticas de treinamento, que eram também favorecidas pela presença da forte tradição de formação vocacional ${ }^{3}$. Essa tradição promovia a capacitação dos jovens em ofícios ligados à indústria, oferecendo oportunidades para indivíduos sem formação acadêmica e contribuindo para uma transição mais suave entre a escola e a indústria.

Importante papel era também desempenhado pelas associações empresariais, que contribuíam para gerar um contexto de confiança em que as empresas sentiam-se seguras para trocar informações e engajarem-se em práticas conjuntas de inovação e desenvolvimento do produto. As associações ajudavam a reduzir a desconfiança em relação ao Estado e a resolver problemas de ação coletiva, de forma a favorecer o engajamento em atividades de pesquisa e desenvolvimento (P\&D). Enfim, arbitravam o processo de negociação com os trabalhadores, inibindo que as firmas roubassem trabalhadores umas das outras. O engajamento conjunto de sindicatos e associações, conhecedores da realidade da empresa, contribuía para a qualidade dos programas de treinamento (Guimarães 2006).

O Estado alemão, embora muito preocupado com a estabilidade monetária, desempenhava importante papel nas políticas de treinamento, no estímulo a atividades de $\mathrm{P} \& \mathrm{D}$, na política regional e no apoio às pequenas e médias empresas. Outra característica era a relação próxima entre bancos e empresas, que garantia uma fonte de capital paciente, requisito para as firmas engajarem-se em estratégias de longo prazo. Além disso, a Alemanha tinha um Estado do Bem-Estar Social que, apesar de muito centrado em práticas contributivas, oferecia um alto grau de proteção aos trabalhadores e aos desempregados, permitindo ao desempregado aguardar um emprego condizente com sua formação.

Essas características institucionais tiveram (e têm) várias implicações, influenciando, por exemplo, as fontes de vantagens comparativas. Os alemães são fortes em produtos sofisticados e dependentes da mão de obra qualificada, incluindo automóveis, máquinas ferramentas e instrumentos médicos. Por sua vez, a Alemanha tende a ser fraca em setores que demandam maior flexibilidade e agilidade de resposta, incluindo nichos do setor serviços. Segundo Streeck (1997), o forte da Alemanha é a capacidade de inovação incremental, sendo fraca na capacidade de inovar radicalmente, dados o número de stakeholders que precisam ser ouvidos e os pontos de veto do sistema político ${ }^{4}$. Outra implicação é o caráter mais social de seu capitalismo, marcado por melhor distribuição de renda e por baixas taxas de pobreza. No pós-guerra, a Alemanha apresentou uma combinação rara entre dinamismo econômico e redução das desigualdades, com crescimento da produtividade, das exportações, dos salá- 
destacava-se em apenas 7 nichos, contra 44 dos Estados Unidos.

${ }^{5}$ Como resultado, tanto o capital como o trabalho passaram a ser regidos por lógicas definidas além do capitalismo alemão. O maior acesso das empresas a novas engenharias financeiras reduziu também o interesse em preservar as relações próximas com os bancos. rios e dos serviços de bem-estar social. Infelizmente, esse arranjo foi fortemente abalado nos anos 1970 .

Algumas dificuldades foram compartilhadas por muitos países, como o arrefecimento cíclico de certos setores, a queda da taxa de lucro e as dificuldades do padrão monetário internacional. Outras foram específicas da Alemanha, que se mostrou lenta para introduzir mudanças e perdeu terreno para a competição japonesa. A desaceleração do crescimento, junto com o aumento do desemprego, trouxe pressões sobre o déficit público e sobre a inflação. Nos anos 1970, o arranjo corporativista ainda permitiu resultados melhores que dos seus vizinhos, mas a incapacidade de lidar com o novo quadro persistiu nas décadas seguintes. A preservação do modelo, baseado em altos salários e direitos trabalhistas, demandava uma situação próxima ao pleno emprego, objetivo que se tornou distante naquele contexto.

É nesse quadro de dificuldades que a unificação alemã vai se inserir, agravando o déficit público. Outro agravante foi a atração de trabalhadores qualificados do Leste europeu, tornando difícil o comprometimento com um modelo de altos salários e negociação salarial centralizada. Enfim, outra fonte de dificuldades veio com a internacionalização produtiva e financeira, que abalou as relações entre bancos e empresas e tornou mais difícil para um país insular suas instituições ${ }^{5}$. Diante desse quadro, muitas das bases do modelo socialmente coordenado viram-se ameaçadas. O desemprego crescente ameaçava as relações de trabalho mais protegidas. A internacionalização financeira colocava em risco a fonte de capital mais paciente. A isso, somavam-se a rigidez do modelo e a baixa capacidade de inovar radicalmente, que tornava mais difícil a inserção em um novo paradigma produtivo tecnológico, baseado na tecnologia da informação, na microeletrônica, na química fina e na biotecnologia. A Alemanha precisava efetuar reformas, mas considerava importante preservar as instituições que favoreciam a negociação e o consenso e que eram, em parte, consideradas responsáveis pelos bons resultados sociais e pelas fontes de vantagens comparativas (Guimarães 2006). As próximas seções exploram as respostas a esses desafios, com destaque para as reformas na governança corporativa, no sistema financeiro e nas relações de trabalho. Mas, antes, considera-se importante situar o modelo alemão dentro da estratégia mais geral de inserção internacional.

\section{III - A Alemanha e a estratégia internacional}

A inserção internacional da Alemanha ajuda a explicar as especificidades da sua trajetória de desenvolvimento. Após a II Guerra Mundial e a divisão do país, o boom econômico verificado na República Federal da Alemanha (RFA) foi decisivo para limitar os apelos dos partidos radicais, legitimar a economia social de mercado e impulsionar a ideia de um mercado comum europeu. A integração à Europa foi uma estratégia para ganhar reconhecimento internacional e para distanciar-se da estratégia expansionista que havia marcado as décadas anteriores. O perfil internacional da Alemanha, desde então, tem se assentado sobre as bases da parceria transatlântica, do multilateralismo, da integração europeia e da reconciliação com os países do Centro e Leste da Europa, além de Israel.

A queda do Muro de Berlim, a reunificação e o aprofundamento tanto da integração europeia como da internacionalização da economia foram críticos para a redefinição da trajetória do país. A transferência das instituições econômicas e políticas para a recém-anexada República Democrática Alemã (RDA) deu-se num momento em que o modelo econômico já não tinha o mesmo vigor. O alto grau de controle da RFA sobre o processo de unificação deu-se em razão da perda de legitimidade do regime comunista e da fraqueza da sociedade civil 
na parte oriental, contando com o apoio unânime das principais instituições ocidentais (sindicatos, empresários, partidos e governo).

A reunificação trouxe grandes expectativas e uma gama de desafios. Para acelerar o processo de transplante das instituições e frear a onda migratória para as regiões mais ricas, o governo Helmut Kohl implantou ambiciosas medidas: (i) garantiu a paridade cambial entre a desvalorizada moeda da RDA e o deutsche mark; (ii) criou uma agência-executiva para conduzir o processo de privatização das empresas estatais e (iii) promoveu transferências líquidas anuais da ordem de US\$ 80 bilhões em gastos com o sistema de bem-estar, subsídios e obras públicas. Os benefícios proporcionaram aumento nos rendimentos e melhorias na qualidade de vida dos cidadãos do Leste, tendo a renda per capita duplicada entre 1991 e 2006 (Straubhaar 2008, p. 103). Em certas regiões, em torno das cidades de Dresden, Jena, Leipzig, Leuna e BerlimBrandenburgo, a modernização produtiva levou à formação de centros economicamente dinâmicos. Contudo, o governo não dimensionou bem os custos do processo. A transição para uma economia social de mercado foi bem mais lenta que o esperado e as empresas do Leste, menos produtivas, enfrentaram dificuldades em consequência dos maiores custos de mão de obra e do câmbio valorizado, de forma que o desemprego subiu significativamente (Mendes \& Pedroti 2009). Os custos fiscais e macroeconômicos foram também substanciais. Além das transferências de recursos, houve grande aumento de gastos com seguro desemprego. Como consequência, a dívida pública aumentou de 41,5\% do PIB, em 1991, para 61,5\% em 1997.

Se por um lado a prioridade dada à unificação implicou a absorção de altos custos financeiros por parte do Tesouro, estimados em 1,6 trilhão de euros em duas décadas, por outro a reunificação fortaleceu o peso populacional, econômico e político da Alemanha dentro da Comunidade Econômica Europeia (Older and Wiser 2010, p. 12). Os atores domésticos perceberam que as fragilidades institucionais da entidade supranacional, somadas à população de mais de 80 milhões de habitantes e à força econômica, favoreciam a ampliação da influência do país (Janning 2008; Mendes \& Pedroti 2009). Em 1992, o Tratado de Maastricht assentou as bases da atual União Europeia e pavimentou o caminho para a moeda única. Ao apoiar a criação de um Banco Central Europeu e abrir mão do poderoso deustche mark, a Alemanha passou a balizar, formal e informalmente, a política monetária europeia.

A Alemanha tem dado apoio sistemático ao fortalecimento da capacidade de ação institucional da União Europeia. Com a mudança no equilíbrio de poder após a entrada em vigor dos Tratados de Amsterdã, em 1999, Nice (2001) e Lisboa (2007), novas alianças e coalizões vêm se constituindo dentro do bloco ${ }^{6}$. Essa nova realidade tem demandado da Alemanha uma capacidade de adaptação para manter a integração europeia como o eixo prioritário de sua inserção internacional. O Tratado de Lisboa, em 2007, foi o ponto máximo desse processo, tendo sido viabilizado por um forte consenso suprapartidário que compatibiliza a linha europeísta pragmática com a defesa dos interesses nacionais (Janning 2008, p. 84).

Katzenstein (1997, p. 120) argumenta que o país leva grande vantagem ao tornar a União Europeia a principal meta e instrumento de sua projeção externa. A Alemanha persegue seus interesses internacionais a partir da Europa, procurando, ao influenciar e moldar as regras do jogo, promover os interesses de longo prazo. Isso explica posições que, sob outra óptica, poderiam ser interpretadas como contrárias a seu interesse, como a decisão de ceder parte do poder aos Estados menores. Explica também sua participação no orçamento europeu bem superior à respectiva participação econômica. Essa postura, entretanto, exige concessões. A intensificação da internacionalização da economia alemã, 
aliada a uma integração crescente à Europa, traz dilemas institucionais para a compatibilização do modelo de capitalismo coordenado com as diretrizes emanadas de Bruxelas. O livre fluxo de capital e de mão de obra dentro das fronteiras europeias e a atratividade de países com menores custos trabalhistas podem desestabilizar o pacto social historicamente construído (Mendes \& Pedroti 2009, p. 282).

Em todo esse processo, a Alemanha vem exercendo grande influência na política monetária europeia, sendo capaz de induzir uma política nos moldes da adotada nos tempos do marco. Em face de sua produtividade e competitividade, a Alemanha muito beneficiou-se da expansão da União Europeia para o Leste, ao facilitar o deslocamento de bens, serviços e fatores de produção, a riscos mais baixos, para os países que pertenciam à Cortina de Ferro (idem). Em 2007, cerca de $10 \%$ dos quase US\$ 1 trilhão em exportações alemãs destinaram-se a essa região (Straubhaar 2008).

Nos últimos anos, tem havido crescimento dos investimentos de firmas alemãs no exterior, assim como de firmas estrangeiras na Alemanha. A Alemanha concentra grande parte dos seus investimentos externos em países desenvolvidos, como os Estados Unidos e o Reino Unido. Entretanto, vem ocorrendo crescimento do investimento direto em países da Europa central e do Leste europeu, centrado principalmente no setor manufatureiro, movimento que indica a adoção de estratégias voltadas a reduzir custos trabalhistas. Outra estratégia vem sendo fortalecer as relações com a Rússia e com países da Ásia, especialmente a China e a Índia. As exportações alemãs para a Ásia cresceram de 33 bilhões de euros, em 1993, para mais de 106 bilhões em 2006, tendo o número de empresas alemãs nesse mercado duplicado e o investimento direto quadruplicado (idem, p. 91).

A crise iniciada em 2007-2008 representou um forte golpe no projeto de uma Europa unida e próspera, evidenciando, entre outros aspectos, as dificuldades inerentes à adoção de uma moeda única em uma entidade marcada por países com expressivas diferenças econômicas. Muitos países sofreram devido ao envolvimento excessivo com inovações financeiras de alto risco, inclusive nos mercados imobiliários. As dificuldades enfrentadas pelos bancos e pela economia engatilharam a intensificação da intervenção estatal, voltada a socializar créditos podres e a introduzir estímulos de demanda, o que resultou em um enorme endividamento público.

O endividamento, no entanto, teve a consequência de ampliar as incertezas ligadas ao mercado financeiro, expandindo o receio de que alguns Estados poderiam ter se expandido além da conta e não seriam capazes de arcar com as dívidas. Os credores passaram a exigir austeridade, passando a enfrentar os mesmos Estados que haviam, alguns anos antes, chantageado a socorrê-los (Streeck 2012). Uma consequência é que o custo da estabilização passou a ser pago por indivíduos comuns, dado que os governos foram obrigados a reduzir drasticamente os gastos visando resgatar a confiança do capital financeiro. Os países foram jogados em recessão, com o agravante de que o receituário tinha poucas chances de recuperar a economia e resgatar a confiança.

Em face de tal situação, a posição do governo alemão tem sido combinar o envio de grandes aportes de recursos para os países em dificuldades com demandas de que equilibrem suas contas e tenham maior responsabilidade fiscal. A intervenção alemã justifica-se pelo duplo intuito de salvar os bancos alemães, fortemente envolvidos, e preservar a credibilidade da zona do euro, sabendo que a falência de algum país membro teria efeitos explosivos. Em alguns momentos, a retórica da chanceler Ângela Merkel enfatizou a necessidade de que parte do ônus fosse assumida pelos próprios bancos, posição logo 
abandonada em face da reação dos mercados e do aumento da instabilidade (idem).

Em face desse quadro, mas também da oposição interna contra o envio de recursos para países considerados imprevidentes, o governo alemão vem agindo com cautela. Por um lado, foi incisivo na proposta de criação de um Fundo Europeu de Estabilidade Financeiro. Pelo outro, tem aproveitado o momento crítico para exigir mais austeridade e reformas institucionais na União Europeia. O objetivo é conferir à Comissão Europeia autoridade para promover a revisão nos orçamentos nacionais, controlar os déficits fiscais e adotar medidas visando reduzir os entraves burocráticos, administrativos e trabalhistas. Seria um passo significativo no fortalecimento da entidade supranacional, mas tende a sofrer forte oposição por parte dos Estados membros (Feldstein 2012, pp. 106-110).

Em suma, a tradição pacifista e integracionista da República Federal da Alemanha, reforçada após os momentos críticos da reunificação e do aprofundamento da integração europeia e da internacionalização econômica, fortalece a condição alemã de principal motor econômico e de principal voz política da Europa, enquanto o país consolida-se como uma praça econômica das mais competitivas. Vinte anos após a queda do Muro de Berlim, as dificuldades de vários países da Europa contrastam com uma Alemanha cada vez mais influente, capaz de ditar as regras e definir os rumos da integração. Muitos são os desafios da zona do Euro, mas as chances de superá-los e de salvar a união europeia passam decisivamente pela Alemanha, que tem reforçado sua liderança.

\section{IV - Governança Corporativa e Sistema Financeiro: características institucionais, mudanças e conservação}

\footnotetext{
${ }^{7}$ Em 1888, uma reforma estabeleceu uma quantidade mínima de ações a ser comprada, conferindo aos bancos um papel essencial como intermediário dessas operações.
}

A Alemanha desenvolveu um modelo muito particular de governança corporativa, cuja origem remonta, como destacado, ao seu processo de modernização conservadora. Um fator essencial foi a resposta adotada ao crescimento das empresas e à separação entre propriedade e controle. Ao contrário dos Estados Unidos, em que essa separação foi acompanhada pela pulverização da posse e por uma orientação mais financeira, o controle na Alemanha foi compartilhado por redes empresariais e bancos, preservando uma estrutura de posse mais estável e comprometida com a empresa (Jackson 2005a). Em resposta aos graves efeitos da depressão do século XIX, foi adotada, em 1884, uma reforma na lei relativa às corporações, revertendo características mais liberais e fortalecendo a regulação. Foi fortalecida a posição tanto dos proprietários familiares como dos bancos, que ganhavam peso no corpo gerencial das empresas, enquanto a posição dos pequenos acionistas era enfraquecida.

No período 1870-1930, o sistema financeiro alemão tinha traços mais liberais, havendo baixa regulação do governo. Grandes bancos, em caráter de sociedade anônima, surgiram a partir de 1870, sendo formados principalmente por proprietários de manufaturas, comerciantes e pequenos bancos, buscando proteger-se de um contexto de maior instabilidade. Em uma fase inicial, os bancos mostravam-se avessos ao risco, os empréstimos eram basicamente de curto-prazo e as firmas, caso desejassem capital de longo prazo, eram aconselhadas a recorrer ao mercado de ações. A necessidade das empresas por capital de longo prazo atraiu os bancos para o mercado de capitais, passando a atuar como intermediadores na compra e venda de títulos e adquirindo ações ${ }^{7}$. Ao adquirir grandes quantidades de ações, os bancos ganhavam assento no conselho administrativo das empresas, o que aumentava o poder de influência nas decisões. No entanto, a ausência de regulamentação culminou em diversas crises no sistema financeiro, como as crises de 1873, 1890, 1907 e 1930, essa última de enorme impacto. Mudanças então foram feitas na direção de um re- 
${ }^{8}$ Segundo Jackson (2005a, p. 149), "codetermination represented a socially integrative alternative to revolution or socialism".

9 Como argumenta Beaud (1989, p. 329), “em 1973, 35 representantes dos três grandes bancos não detinham menos que 324 mandatos de conselhos fiscais das empresas alemãs".

${ }^{10}$ Em 1991, por exemplo, ocorreram apenas 19 IPOs (Initial Public Offering, ou seja, oferta inicial de ações pelas empresas) na Alemanha, contra 663 nos Estados Unidos. gime regulatório que desse preferência aos bancos em vez do mercado de capitais (Vitols 2005a).

As crises e dificuldades enfrentadas pela Alemanha, incluindo a depressão do século XIX e os impactos da derrota na I Guerra Mundial, favoreceram também a aproximação das empresas e a formação de cartéis, facilitando a disseminação de associações empresariais e de práticas de cooperação entre empresas do mesmo setor. Destaca-se a grande diferença em relação aos Estados Unidos, em que o rigor da Lei Anti-Truste dificultou a associação entre as empresas, favorecendo estratégias de fusão e implicando pouco desenvolvimento de laços de interação entre as empresas.

Em relação à participação dos trabalhadores, destaca-se a criação de canais de participação e de outros benefícios em troca do apoio à empresa ${ }^{8}$. Inicialmente, os sindicatos eram proibidos e perseguidos, mas fortaleceram-se como resultado do ritmo acelerado de industrialização. As grandes firmas, visando burlar a interferência dos sindicatos, procuraram organizar-se fora das grandes cidades e concederam canais internos de participação como forma de conquistar apoio. Com a República de Weimar, os sindicatos ganharam influência e foi promulgada, em 1920, a Lei dos Conselhos de Trabalho (Works Councils Law), aprofundando o papel da codeterminação na economia alemã. Essa lei continha muitos pontos do que viria ser o modelo alemão, incluindo a cooperação pacífica dos conselhos trabalhistas nos assuntos das firmas e a paridade nas decisões relativas à política de pessoal.

Em suma, esses traços contribuíram para que a Alemanha tivesse, no pós-guerra, um modelo de governança corporativa marcado pela estrutura de propriedade mais concentrada, pela influência dos bancos ${ }^{9}$ e pela participação dos trabalhadores. Como consequência, as empresas não sofriam pressão para maximizar a lucratividade de curto prazo, como ocorreria no caso de maior influência dos acionistas. Consolidou-se um capitalismo de stakeholders, em que a preocupação com os resultados financeiros deveria ser conciliada com uma estratégia que privilegiasse o desempenho no respectivo nicho e apresentasse sustentabilidade no longo prazo.

Um pilar desse modelo foi a existência de uma fonte de capital paciente. No imediato pós guerra, o mercado de capitais foi incentivado pelas forças aliadas, mas a forte regulamentação foi preservada, tornando-o menos atrativo para as empresas, bancos e famílias. Além disso, outros fatores inibiram o desenvolvimento do mercado de capitais: as empresas eram capazes de autofinanciarem-se e havia grande disponibilidade de crédito por parte dos bancos. Por sua vez, em uma economia marcada por menor desigualdade de renda, os agentes familiares tendiam a mostrar-se mais avessos ao risco e os fundos de pensão privilegiavam aplicações mais seguras, implicando menor grau de capitalização. Como consequência, as formas de financiamento foram, até o final da década de 1990, basicamente oriundas dos bancos, com uma parcela reduzida dos ativos financeiros originando-se do mercado de capitais. O número de empresas que lançavam ações no mercado de capitais era muito inferior aos Estados Unidos ${ }^{10}$.

A partir das décadas de 1970 e 1980, a maior internacionalização da economia acarretou pressões sobre o modelo de governança corporativa, que tem se tornado mais orientado financeiramente. Em 1998, foi aprovada a reforma na legislação da governança corporativa, a Lei de Fortalecimento do Controle e da Transparência (KonTraG), cujos objetivos incluíam o fortalecimento dos padrões de contabilidade e a adoção de regimes regulatórios mais favoráveis à transparência, à divulgação de informações e ao monitoramento por atores externos à empresa. A Lei também autorizava as empresas a ofertar ações para os gerentes e funcionários como bônus e aumentava a proteção aos pequenos acionistas. Assim, a KonTraG limitou o poder dos corpos admi- 
nistrativos das empresas, havendo redução tanto na participação dos bancos nos conselhos de direção como no peso dos trabalhadores em certas decisões. Pouco depois, as aquisições hostis (takeovers) foram legalizadas, tendo ocorrido, em 1999-2000, o importante takeover da Mannesmann pela Vodafone. Porém, o número de takeovers continuou baixo, o que pode ser explicado pela recusa dos bancos a fornecer recursos para as operações, temendo que tal atitude viesse a afetar as relações banco-cliente (Heckethal, SCHIMIDT \&AMP; TYRELL 2006).

Em face da interdependência que marca as instituições, pergunta-se em que grau a nova orientação da governança corporativa poderia comprometer outras características do modelo, incluindo as relações de trabalho mais estáveis. Como mostra Jackson (2005b), vem havendo redução nas diferenças entre o modelo alemão e o anglo-saxão, mas não se pode falar de convergência. Cada país tem sua forma de responder aos desafios, o que é influenciado pelo arcabouço institucional. No caso alemão, as mudanças têm se dado concomitantemente à preservação de aspectos importantes do capitalismo coordenado. A posse do capital continua concentrada e os investimentos comprometidos com a empresa, sendo limitado o número de investidores orientados financeiramente. Destaca-se a preservação da participação dos trabalhadores e de outros stakeholders, que, embora aceitando um papel maior para os pequenos investidores, continuam ativos. A participação dos trabalhadores tem sido essencial para que a firma adote um horizonte de longo prazo e preserve relações de trabalho mais estáveis.

Algo semelhante tem ocorrido em relação ao sistema financeiro. A partir da década de 1990, atores passaram a pressionar para que mudanças fossem feitas. Entre os atores, Vitols (2005b) destaca: (i) os grandes bancos, dada a queda nos lucros a partir dos anos 1980; (ii) ministros do governo, visando impulsionar o setor de alta-tecnologia e (iii) executivos que se identificavam com o modelo norte-americano. Além disso, políticas foram adotadas visando fortalecer a posição da Alemanha no cenário internacional, com destaque para a Segunda Lei para a Promoção dos Mercados Financeiros, de 1994, que buscava adotar práticas semelhantes às existentes nos Estados Unidos (Vitols 2005b). A Lei criou a Comissão Federal de Títulos (Federal Securities Trading Commission), encarregada de monitorar as transações. Seus objetivos eram aumentar a transparência do mercado de ações, dar maior proteção aos pequenos investidores e incentivar a criação de diferentes tipos de fundos de investimento.

Entretanto, certas deficiências persistiram e o sistema financeiro é ainda caracterizado pelo fraco suporte às empresas de alta tecnologia que, por apresentarem uma dinâmica de negócios de alto risco, são incapazes de apresentar as garantias exigidas pelos bancos. Para reverter esse quadro, programas públicos foram criados e expandidos e garantias foram oferecidas para que a iniciativa privada participasse dos financiamentos. Em 1997, foi criado o Neuer Market como um segmento separado do mercado de ações de Frankfurt, buscando atender às necessidades de empresas em rápido desenvolvimento. Como resultado, o número de novas empresas que lançaram ações no Neuer Market aumentou significativamente ${ }^{11}$. Porém, com o estouro da bolha de 2001, o número de empresas presentes no Neuer Market caiu para níveis inferiores aos verificados no momento de sua criação, levando ao fechamento do mercado em 2003 e implicando em forte golpe sobre a confiança no mercado de capitais.

Em grande parte, as mudanças no sistema financeiro estão relacionadas ao processo de internacionalização financeira. Novas formas de financiamento surgiram, as instituições financeiras adquiriram alcance mais global e a concorrência se intensificou. Como consequência, tornou-se mais difícil para os bancos alemães obterem lucro a partir das atividades de empréstimos e depó-

${ }^{11}$ Além disso, o parlamento aprovou, em 2001, reformas no sistema de pensão visando aumentar o fluxo de recursos para os mercados de capitais 
12 No período 1993-2003, os bancos reduziram a participação nas empresas de $12,8 \%$ para $9 \%$ e as famílias de $19,9 \%$ para $13,9 \%$, enquanto as empresas de seguro aumentaram de $6,6 \%$ para $13,2 \%$.

${ }^{13}$ Esses números, em 1993, eram respectivamente $76 \% \mathrm{e}$ $18,3 \%$. sitos. A resposta foi buscar distanciar-se das empresas, oferecendo serviços como gerenciamento de ativos e atuando como bancos de investimento. Como resultado desse processo e das novas leis de governança corporativa, os bancos afastaram-se dos conselhos administrativos das empresas. Esse espaço, no entanto, foi preenchido pelos gerentes aposentados e por companhias de seguro, preservando a estrutura de propriedade mais estável e não alterando drasticamente a forma de atuação das empresas (Hackenthal, Schmidt \& Tyrell $2005)^{12}$. Cabe também destacar que a tendência de distanciamento dos bancos não é observada entre as pequenas e médias empresas, que ocupam papel bastante relevante na economia alemã. Essas, incapazes de financiarem-se no longo-prazo, mantêm relação estreita com os bancos.

Apesar das mudanças expostas, o núcleo do sistema financeiro alemão não tem apresentado mudanças drásticas. Em 2005, os bancos públicos possuíam $35 \%$ dos ativos totais no sistema bancário, seguidos pelos bancos comerciais (28\%) e pelos bancos das cooperativas (12\%) (Hackenthal, Schmidt \& Tyrell 2006). Em 2003, o setor bancário possuía $72 \%$ dos ativos do sistema financeiro, seguido pelo setor seguros $(17 \%)^{13}$. No período $1991-2003$, as poupanças das famílias preservaram uma estrutura similar: depósitos bancários e dinheiro passaram de $57,8 \%$ para $58,3 \%$, enquanto a aplicação em seguros passou de $31,9 \%$ para $30 \%$ (Vitols 2005b). Assim, apesar da diversificação das atividades bancárias, que foi menos expressiva do que a tendência mundial, os bancos continuam a fornecer a maior parte do financiamento para o setor empresarial, conservando papel central no sistema financeiro. A existência dessa fonte de capital mais estável é essencial para a preservação de outros traços do capitalismo alemão.

\section{V - Relações de trabalho: persistência e mudanças}

Uma característica central do modelo alemão, cujo auge deu-se no período 1950-1973, são as relações de trabalho e o papel desempenhado pelos sindicatos. As negociações salariais davam-se em nível setorial, contribuindo para a baixa diferenciação salarial. Nas empresas, as práticas de codeterminação davam aos trabalhadores representação nas decisões, enquanto sindicatos e associações empresariais participavam de importantes decisões a nível nacional. $\mathrm{O}$ arranjo produzia um ambiente de cooperação e confiança que incentivava o investimento em capacitação. A excelência da força de trabalho contribuía para as vantagens comparativas em produtos mais elaborados e para o bom desempenho exportador.

Esse arranjo passou a enfrentar dificuldades nos anos 1970, marcados por profundas mudanças no mundo do trabalho. A crise do fordismo foi acompanhada pela redução do emprego industrial e pela exigência de maior flexibilidade em aspectos das relações de trabalho. Outro desafio veio da competição japonesa e da lenta resposta das firmas alemãs. As dificuldades seriam amplificadas nos anos 1990 como resultado da oferta de trabalhadores do Leste europeu e dos efeitos da unificação alemã, que aumentaram as dificuldades para as empresas cumprirem o acordo, ampliando também as oportunidades para aquelas dispostas a deixar o arranjo. A tudo isso somaram-se os efeitos da internacionalização e da competição crescente, colocando em xeque o mais regulamentado sistema alemão.

A reação inicial aos desafios subestimou a magnitude dos mesmos e as mudanças no mundo do trabalho. O objetivo foi preservar o arranjo, associado à prosperidade verificada no período anterior. $\mathrm{O}$ governo decidiu proteger alguns setores, ao mesmo tempo em que adotava práticas como a extensão do ciclo escolar e a antecipação da aposentadoria, visando reduzir a oferta de trabalho. Os resultados foram frustrantes, ao mesmo tempo em que a rígida legislação 
14 Apesar das dificuldades, eram fortes as forças de resistência a mudanças, principalmente por parte dos sindicatos e de segmentos do partido social democrata. A estrutura política institucional, marcada por governos de coalizão e por muitos pontos de veto, dificultava a aprovação de mudanças. ${ }_{15} \mathrm{O}$ fato de ser adotado pelo líder do partido social democrata, que enfrentou grande resistência dentro de seu partido, atesta a magnitude do desafio e a necessidade das reformas.

${ }^{16}$ Foram também defendidos o fortalecimento do treinamento e os estímulos à inovação e à melhoria educacional, além da redução da burocracia e do red tape, visando tornar a economia mais ágil e flexível.

${ }^{17}$ Segundo o diagnóstico, essas políticas provocavam desemprego de longo prazo e grande número de pessoas dependentes do benefício. trabalhista não estimulava a criação de novos empregos. Enquanto os trabalhadores empregados continuavam protegidos, crescia o número de indivíduos incapazes de conseguir um posto de trabalho, contribuindo para o substancial aumento do desemprego de longo prazo $^{14}$.

Após anos de dificuldades, mudanças mais profundas amadureceram e foram aprovadas. Um marco foi a aprovação da Agenda 2010, em 2002 ${ }^{15}$, defendida como uma série de mudanças necessárias para preservar os avanços sociais do modelo alemão. Para esse fim, era fundamental enfrentar o desemprego e criar condições que estimulassem a oferta de postos de trabalho, tornando o modelo mais flexível e reduzindo os custos de trabalho e as pressões sobre o Estado de Bem-Estar (Guimarães 2006).

Medidas foram adotadas para reduzir a proteção ao emprego em empresas com até dez trabalhadores, tendo também sido suspensa a proibição de demitir indivíduos com mais de 50 anos. Ao mesmo tempo, foi liberalizada a permissão para a contratação de trabalhadores em tempo parcial e para contratos por tempo determinado, que poderiam ser firmados em até quatro anos e sem regulamentação para demissão. Outro alvo foi facilitar a situação das pequenas empresas, aquelas que mais sofriam com as exigências da legislação trabalhista. Portanto, o intuito era viabilizar empregos que seriam mais difíceis em um contexto de forte regulamentação ${ }^{16}$. Outra linha avançada pela Agenda e pelas reformas posteriores foi a redução na duração do seguro desemprego, no intuito de pressionar a volta dos indivíduos ao mercado de trabalho. O seguro desemprego podia durar até 32 meses, em um valor que variava de $60 \%$ a $67 \%$ do salário prévio. Além disso, o indivíduo poderia recusar propostas de emprego se fossem diferentes da sua ocupação prévia ${ }^{17}$. Com as novas direções, a duração do benefício baixou para 12 meses (18 meses para os maiores de 55 anos). Uma vez expirado, o trabalhador teria direito ao benefício tipo II, no valor de apenas 345 euros (Seeleib-Kaiser \& Fleckenstein 2007).

Alguns anos após a implementação dessas medidas, houve queda tanto da taxa de desemprego (Tabela 1) como do desemprego de longo prazo, indicando a maior sensibilidade da criação de empregos ao crescimento econômico. Essas medidas foram acompanhadas de uma reestruturação das políticas de emprego, com ênfase principalmente na melhoria dos sistemas de intermediação e de acompanhamento profissional, voltados a reinserir o indivíduo no mercado de trabalho. A política passava a ser concentrada em centros integrados de emprego (job centers), que reuniam as ações necessárias para ativar o indivíduo e ampliar as chances de reinserção. Seeleib-Kaiser e Fleckenstein (idem) mos-

Tabela 1 - Taxa de Desemprego da Alemanha

\begin{tabular}{lc}
\hline Ano & $\%$ \\
\hline Dez 1992 & 8,1 \\
Dez 1995 & 9,9 \\
Dez 2000 & 9,3 \\
Dez 2002 & 10,1 \\
Dez 2004 & 10,8 \\
Dez 2006 & 9,6 \\
Dez 2008 & 6,9 \\
Dez 2010 & 6,8 \\
Dez 2011 & 5,6 \\
\hline
\end{tabular}

Fonte: Trading Economics (2011). 
tram como os alemães adotaram várias direções presentes no Reino Unido, país criticado pela baixa proteção dada aos trabalhadores.

Mudanças importantes também ocorreram dentro das empresas. Jackson (2005b) sinaliza como a redução do emprego na Alemanha, entre 1991 e 2000, foi apenas levemente inferior à verificada nos EUA, não muito diferente da média dos países avançados. Reportagem da revista The Economist (Older and Wiser 2010) destaca que o custo do trabalho caiu, entre 2000 e 2008, 1,4\% ao ano na Alemanha, contra 0,7\% nos EUA, $0,8 \%$ na França e $0,9 \%$ na Grã-Bretanha. Esses números apontam para mudanças adotadas no intuito de enfrentar os desafios, mudanças que vêm contando com a participação dos trabalhadores. Segundo a The Economist, as respostas, importantes para a rápida reação alemã à crise iniciada em 2007, devem-se às "particularidades de sua engenhosa engrenagem institucional". O ponto destacado é a participação dos trabalhadores e a capacidade de fazer concessões, dando legitimidade ao processo e facilitando os ajustes. Durante a crise, houve queda dos salários e das horas trabalhadas, com o ajuste feito por meio do banco de horas, de forma a preservar o emprego. Segundo a reportagem, a introdução dessas práticas deu flexibilidade ao modelo, afastando-o da rigidez característica de dez anos atrás.

Em outras palavras, está em curso um processo de reestruturação, em que se destaca a participação dos trabalhadores e a adoção de concessões em troca da manutenção do emprego. Mudanças ocorreram nas regras de governança corporativa, implicando maior autonomia dos gerentes e redução da representação dos trabalhadores em certas decisões. Entretanto, os canais de consulta continuam abertos e a codeterminação continua fundamental para a estabilidade nas relações de trabalho. Os trabalhadores concordam com a redução dos benefícios e com a flexibilização das horas de trabalho, firmando acordos para evitar a migração de plantas para outros países. Em todo o processo, a redução do emprego vem sendo feita de forma acordada, visando evitar demissões. Uma prática recorrente é a antecipação da aposentadoria, que conta com a ajuda do Estado, assumindo parte do ônus do ajuste.

Assim, o processo vem demonstrado alto grau de flexibilidade. Nos últimos anos, houve crescimento dos salários, embora abaixo da produtividade, indicador de que os trabalhadores ganharam mas também cederam. Lapavitsas et al. (2010) mostram que os custos unitários nominais de trabalho subiram menos que em outros países europeus. Esses resultados foram fundamentais para a dinamização das exportações para a zona do euro, que reponde por quase metade do total das exportações alemãs. Portanto, há indícios de que a capacidade de ajuste, ao promover flexibilidade, vem contribuindo para o bom desempenho da economia e das exportações, ao mesmo tempo em que preserva os direitos. Os trabalhadores participam e concordam com as mudanças, incluindo mudanças na governança corporativa que ampliaram a participação dos acionistas. Mas sua participação é fundamental para impedir que os gerentes persigam estratégias muito baseadas em considerações de curto prazo. Assim, apesar das mudanças ocorridas na governança corporativa e no sistema financeiro, a Alemanha vem preservando a ênfase em relações de trabalho mais pacientes, havendo indícios de que as particularidades institucionais vêm contribuindo para os bons resultados ${ }^{18}$. A despeito dos desafios persistentes, o arranjo permite aos alemães conservarem a qualidade do produto, fundamental para o bom desempenho exportador e para a manutenção de uma força de trabalho com altos salários.

Em síntese, as mudanças e concessões apontam para o fato de que ajustes precisaram ser feitos. O seguro desemprego ficou mais rígido e mudanças ocorreram na legislação trabalhista. Os salários perderam participação na renda, o que se explica pela redução do emprego e pelo maior número de trabalhadores 
sujeitos a contratos atípicos e com menos direitos. Outras alterações indicam a redução da filiação a sindicatos e a associações empresariais, de forma que um número menor de trabalhadores continua coberto pelas negociações setoriais. A despeito das mudanças, que implicaram maior desigualdade de renda, o modelo alemão continua a ter especificidades, que se traduzem em indicadores sociais acima da média da Organização para Cooperação e Desenvolvimento Econômico (OECD) e em relações de trabalho que preservam alto grau de participação dos trabalhadores.

\section{VI - As novas tendências e os desafios para a economia alemã}

Os frutos do capitalismo coordenado são bem ilustrados pelo bom desempenho exportador. As exportações transformaram-se no centro dinâmico da economia, respondendo em média por um terço do PIB e alcançando posições de liderança em indústrias de alto valor agregado. Nota-se que o peso do setor externo é muito maior do que em seus pares, notadamente EUA e Japão (Tabela 2). As taxas de crescimento das exportações encontram-se entre as maiores do mundo desenvolvido, com destaque para as duas últimas décadas, período marcado pela formação e expansão da Zona do Euro (Gráfico 1).

A Zona do Euro é de especial importância para a Alemanha, dado que quase metade das suas exportações tem como destino os países do bloco. Fora do continente, o principal comprador são os Estados Unidos (Gráfico 2). Destacam-se, como principais produtos de exportação, máquinas-equipamentos, veículos, equipamentos eletroeletrônicos, produtos químicos, plástico e instrumentos médicos, setores em que a Alemanha tem forte tradição (Porter 1993).

Como se vem argumentando, o desempenho exportador alemão está relacionado à estrutura organizacional de suas firmas e ao grau de coordenação de seu modelo de capitalismo. O sucesso das corporações está ligado à relação estabelecida entre bancos e empresas, à qualificação e especialização da mão-

Tabela 2 - Coeficiente de Exportações (\% do PNB)

\begin{tabular}{lccccc}
\hline País & 1976 & 1984 & 1992 & 2000 & 2008 \\
\hline Alemanha & 18 & 23 & 25 & 30 & 47 \\
EUA & 8,2 & 8 & 10 & 11 & 12 \\
Japão & 13 & 14 & 10 & 10,2 & 17,8 \\
\hline
\end{tabular}

Fonte: Trading Economics (2014).

Gráfico 1 - Alemanha: taxa de crescimento anual de exportações de bens e serviços.

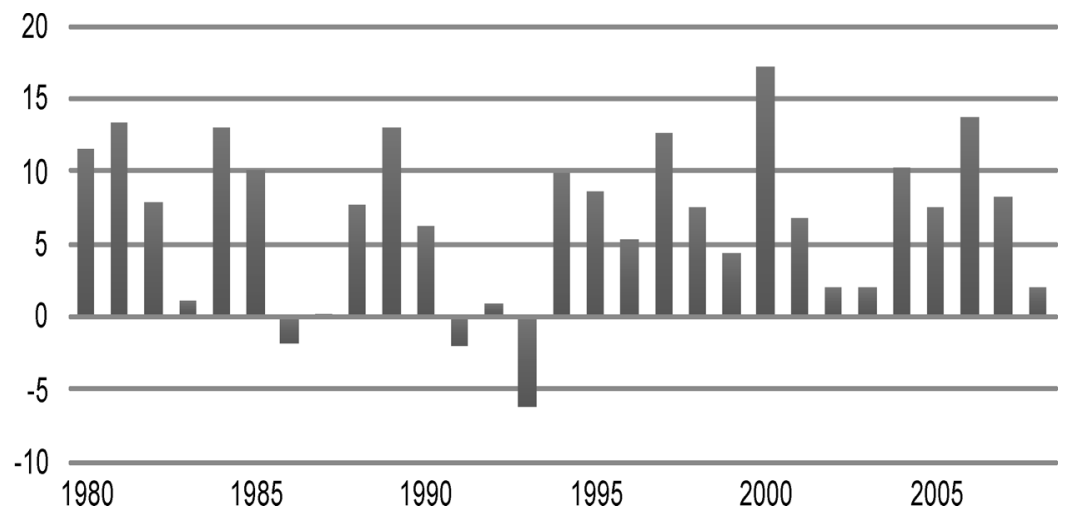

Fonte: Alemanha (2013). 
19 Como ilustração do potencial exportador e da capacidade de reação do país, destaca-se o saldo em transações correntes em 2007, que atingiu US\$ 267 bilhões, após ter atingido valores negativos logo após a unificação.
Gráfico 2 - Destino das Exportações Alemanha (2007) (Valores em US\$ FOB)

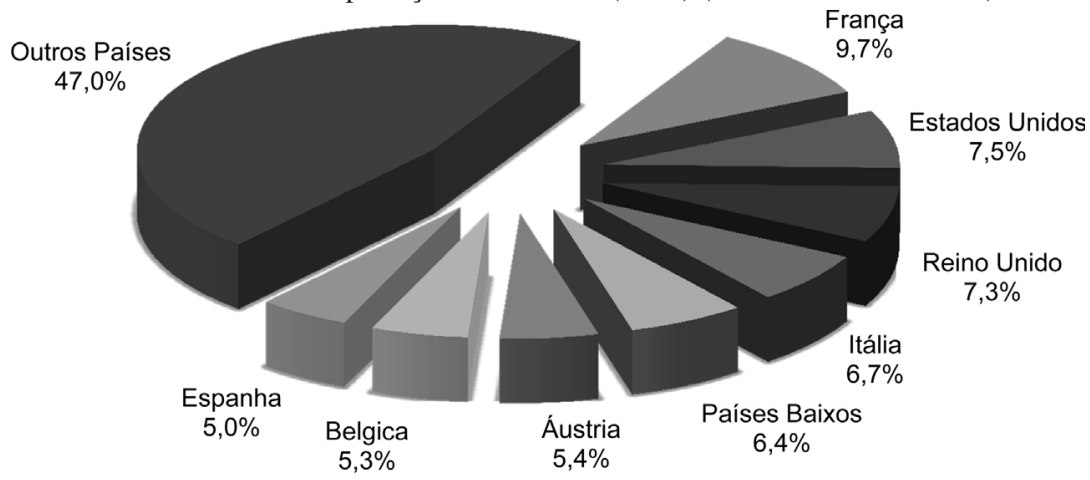

Fonte: Brasil (2014a).

de-obra e às práticas de codeterminação. As formas de cooperação permitiram estabelecer um ambiente de confiança entre os agentes (inclusive o governo), amenizando e revertendo os impactos negativos advindos da baixa oferta de recursos naturais, dos custos energéticos elevados e dos altos salários. Logo, a presença de mecanismos de aprimoramento dos recursos humanos e técnicos tornou-se um elemento-chave, uma vez que os ganhos de competitividade estão relacionados à alta produtividade e à qualidade e diferenciação de produtos, $\mathrm{e}$ não à redução dos custos trabalhistas (Tabela 3) ${ }^{19}$.

O compartilhamento de informações também potencializou os resultados na área de pesquisa e desenvolvimento e, como resultado, a Alemanha atingiu grande destaque nos setores químico, automotivo e de bens de capital. A concentração geográfica reforça essa vantagem, uma vez que

"na Alemanha, as universidades e escolas individuais tendem a especializar-se em campos relacionados com as necessidades das indústrias locais e desenvolvem fortes conhecimentos nessas áreas" (idem, p. 419).

Tabela 3 - Custos de mão-de-obra e produtividade do trabalho (2004)

\begin{tabular}{|c|c|c|c|}
\hline País & $\begin{array}{c}\text { Custo total da } \\
\text { mão-de-obra (US\$ } \\
\text { por hora) }\end{array}$ & $\begin{array}{c}\text { Custo total da } \\
\text { mão-de-obra - } \\
\text { Índice Reino Unido } \\
=100\end{array}$ & $\begin{array}{c}\text { Produtividade da } \\
\text { mão-de-obra - } \\
\text { Índice Reino Unido } \\
=100\end{array}$ \\
\hline México & 2,3 & 14,3 & 40,3 \\
\hline Coréia do Sul & 8,1 & 50,3 & 43,5 \\
\hline Espanha & 10,9 & 67,7 & 90,3 \\
\hline Austrália & 13,2 & 82 & 99,8 \\
\hline Itália & 13,8 & 85,7 & 122,6 \\
\hline Canadá & 15,6 & 96,9 & 103,2 \\
\hline França & 15,9 & 98,8 & 135,5 \\
\hline Reino Unido & 16,1 & 100 & 100 \\
\hline Holanda & 19,3 & 119,9 & 129 \\
\hline Japão & 19,6 & 121,8 & 92 \\
\hline Estados Unidos & 20,3 & 126,1 & 125,9 \\
\hline Dinamarca & 22 & 136,6 & 124,9 \\
\hline Alemanha & 22,9 & 142,2 & 127,4 \\
\hline
\end{tabular}

Fonte: Os autores, a partir de Fleury e Fleury (2007, p. 47). 
Tabela 4 - Pesquisadores e artigos científicos e técnicos publicados entre 1981 e 2000

\begin{tabular}{|c|c|c|c|c|c|c|}
\hline \multirow[t]{2}{*}{ País } & \multicolumn{3}{|c|}{$\begin{array}{c}\text { Pesquisadores por Milhão de Habitantes - } \\
\text { Equivalente em Tempo Integral }\end{array}$} & \multicolumn{3}{|c|}{ Artigos Científicos e Técnicos Publicados } \\
\hline & 1981 & 2009 & Variação (\%) & 1981 & 2009 & Variação (\%) \\
\hline EUA & $2973^{\mathrm{a}}$ & & & 132278 & 208601 & 57,7 \\
\hline Japão & $3934^{\mathrm{b}}$ & 5147 & 30,8 & 25088 & 49627 & 97,8 \\
\hline Alemanha & 1596 & 3814 & 139 & 26837 & 45003 & 67,7 \\
\hline Reino Unido & 2254 & $4151^{\mathrm{c}}$ & 84,2 & 30794 & 45649 & 46,1 \\
\hline França & 1580 & $3727^{d}$ & 135,9 & 18567 & 31748 & 71 \\
\hline Canadá & 1573 & 4317 & 174,4 & 14440 & 29017 & 100 \\
\hline Itália & 921 & 1691 & 83,6 & 7803 & 26755 & 242,9 \\
\hline
\end{tabular}

${ }^{a}$ Não inclui as áreas de direito, humanas e educação.

${ }^{b} \mathrm{Não}$ inclui as áreas de ciências sociais e humanas no setor produtivo (P\&D integrado).

'Baseado em estimativa nacional.

${ }^{\mathrm{d} E x c l u i}$ a área de defesa (na sua totalidade ou na maioria).

Fonte: Os autores, a partir de Unesco (1999); Unesco Institute for Statistics (2014); The World Bank (2013).

${ }^{20} \mathrm{O}$ intuito das Tabelas $4,5 \mathrm{e}$ 6 foi reunir países que, por seu porte e grau de

desenvolvimento, são de alguma forma comparáveis à Alemanha.
A publicação científica do país encontra-se entre as maiores da Europa, muito próxima à do Reino Unido, em 2009 (Tabela 4) ${ }^{20}$. Mas é enorme a distância em relação aos Estados Unidos, naquilo que não é considerado um ponto forte dos modelos de capitalismo coordenado (Guimarães 2006). Ao comparar o número de pesquisadores por habitantes, nota-se que a Alemanha encontra-se próxima à França, mas abaixo do Reino Unido, do Canadá, do Japão e dos Estados Unidos (Tabela 4). O mesmo vale para o número de

Tabela 5 - Pedidos de patentes de invenção depositados no Escritório de Marcas e Patentes dos Estados Unidos (1980 e 2009)

\begin{tabular}{lccc}
\hline País & 1980 & 2009 & Variação (\%) \\
\hline EUA & 62098 & 224912 & 262,2 \\
Japão & 12951 & 81982 & 533 \\
Alemanha & 9765 & 25163 & 157,7 \\
Inglaterra & 4178 & 10568 & 152,9 \\
França & 3331 & 9331 & 180,1 \\
Canadá & 1969 & 10309 & 423,6 \\
Itália & 1501 & 3940 & 162,5 \\
\hline
\end{tabular}

Fonte: USPTO (2010).

Tabela 6 - Participação no mercado mundial dos produtos intensivos em P\&D (1989)

\begin{tabular}{lcc}
\hline & Tecnologia de ponta & $\begin{array}{c}\text { Tecnologias médias ou } \\
\text { avançadas }\end{array}$ \\
\hline Alemanha & 14,4 & 21,5 \\
França & 7,5 & 6,9 \\
Reino Unido & 10 & 5,8 \\
Estados Unidos & 27,8 & 11,9 \\
Japão & 18,3 & 22,2 \\
\hline
\end{tabular}

Fonte: Raimundo (2009), p. 16. 
${ }^{21}$ Em 2010 os gastos eram de US\$ 203000 por pesquisador na Alemanha; US\$ 207000 nos EUA; US\$ 163000 no Reino Unido e US\$ 152000 no Japão. Em 2010, os mesmos passaram para US\$ 263000 na Alemanha, US\$ 223000 no Japão e US\$ 151000 no Reino Unido.

${ }^{22}$ Uma característica que se pronunciava no final dos anos 1980 e que em grande parte se mantém (Tabela 6). pesquisadores por trabalhador ocupado: em 2010, a Alemanha possuía 8,1 pesquisadores para cada mil pessoas ocupadas, contra 9,6 nos EUA e 10,2 no Japão (Brasil 2014b).

No que diz respeito à produção tecnológica, os gastos por pesquisador estão entre os mais elevados do mundo ${ }^{21}$, mas isso não se reflete na produtividade dos mesmos. Nos pedidos de patente, a Alemanha supera amplamente a França e a Inglaterra, mas encontra-se muito atrás dos Estados Unidos e do Japão. Em 1980, a diferença entre Alemanha e Japão era relativamente pequena, mas em 2009 os japoneses apresentaram resultados três vezes superiores (Tabela 5). Os resultados obtidos pela Alemanha estão relacionados a certas características institucionais, destacando o alto grau de especialização em alguns setores e um padrão de inovação que é muito mais incremental que radical. Além disso, a Alemanha tende a destacar-se mais em setores caracterizados por tecnologias médias, típicos do paradigma fordista ${ }^{22}$.

O anuário World Intellectual Property Organization (WIPO 2010) apresenta a distribuição de inovações dos países pelos diversos campos de tecnologia. A Alemanha apresenta resultados inferiores ao Japão e Estados Unidos em diversos campos (Tabela 7). A principal exceção é o campo engenharia mecânica, em que a Alemanha supera os Estados Unidos e rivaliza com o Japão em vários nichos. Resultados muito positivos são verificados também em nichos do setor químico, com destaque para produtos farmacêuticos, engenharia química e tecnologia ambiental. $\mathrm{O}$ atraso relativo alemão é maior em certos nichos intensivos em conhecimento, incluindo biotecnologia, semicondutores e nichos do setor eletrônico e de telecomunicações. Essa desvantagem é preocupante quando se considera que são nichos com alta capacidade de interação com outros setores industriais e com nichos do setor serviços.

Além disso, observa-se na Alemanha o baixo dinamismo inovador de suas universidades, como ilustrado pela lista de requerimentos de patentes do Patent Cooperation Treaty (PCT), apresentado pelo WIPO de 2010. Em 2009, não há representantes alemães entre os 50 maiores aplicantes, que são, sobretudo, universidades dos Estados Unidos, havendo também representantes do Japão (6), da Coréia do Sul (4), de Israel, do Reino Unido, de Singapura e da Dinamarca. Porter (1993) já apontava a dificuldade alemã em comparar-se aos EUA em inventividade e ao Japão em lançamento de produtos novos, principalmente em setores como computadores, softwares, bioengenharia, produtos eletrônicos e equipamentos de telecomunicações. Segundo Porter (idem), havia um agravante: as universidades alemãs de Ciências Sociais e Administrativas não tinham a mesma eficiência que as de engenharia, engessando a prática de

Tabela 7 - Registro de Patentes por campo de tecnologia e país de origem (2003-2007)

\begin{tabular}{lcccccccccc}
\hline $\begin{array}{l}\text { Campo de } \\
\text { Tecnologia }\end{array}$ & China & $\%$ & Alemanha & $\%$ & Japão & $\%$ & $\begin{array}{l}\text { Coréia } \\
\text { do Sul }\end{array}$ & $\%$ & EUA & $\%$ \\
\hline $\begin{array}{l}\text { Engenharia } \\
\text { Eletrica }\end{array}$ & 10642 & 55,34 & 54434 & 33,26 & 140118 & 42,69 & 56775 & 62,16 & 100989 & 33,12 \\
Instrumentos & 2350 & 12,22 & 19050 & 11,64 & 58502 & 17,83 & 11725 & 12,84 & 53555 & 17,57 \\
Química & 2747 & 14,29 & 27018 & 16,51 & 47236 & 14,39 & 8335 & 9,13 & 81609 & 26,77 \\
Engenharia & 2302 & 11,97 & 52570 & 32,12 & 71211 & 21,70 & 9250 & 10,13 & 50270 & 16,49 \\
Mecânica & & & & & & & & & & \\
Outros campos & 1188 & 6,18 & 10605 & 6,48 & 11117 & 3,39 & 5253 & 5,75 & 18451 & 6,05 \\
Total & 19229 & 100 & 163677 & 100 & 328184 & 100 & 91338 & 100 & 304874 & 100 \\
\hline
\end{tabular}

Fonte: os autores, a partir de WIPO (2010). 
${ }^{23}$ Programme for International Student

${ }^{24}$ Um indício das dificuldades é que algumas firmas têm procurado mesclar formação vocacional e universitária. A BMW, por exemplo, envia um quarto dos seus aprendizes para formação em ciência aplicada. novos princípios/modelos organizacionais, o que ajudava a explicar a "importação" de estrangeiros para o comando das empresas.

Portanto, os indicadores acima apontam dificuldades da Alemanha para ingressar com sucesso no novo paradigma produtivo-tecnológico. A Alemanha continua a ter resultados muito expressivos no que diz respeito à qualidade dos seus produtos e na competitividade das suas exportações, mas tem como deficiência a baixa capacidade de inovação radical e o baixo dinamismo em muitos setores de ponta. Outra dificuldade relaciona-se ao baixo grau de empreendedorismo, sendo reduzido o número de alemães que convertem boas ideias em negócios (Older and Wiser 2010). Entre os que o fazem, muitos tendem a migrar para os Estados Unidos. Além disso, é baixo o número de jovens engajados em atividades inovadoras, bem como a proporção de cientistas alemães entre 25 e 34 anos. Portanto, há indícios de que as universidades falham em fomentar novos negócios, havendo tanto dificuldades para identificar os setores emergentes como poucos incentivos para o ingresso em novos setores. A baixa capacidade de o setor financeiro financiar setores emergentes também contribui para esse quadro.

Há também fortes indícios de problemas no sistema educacional, como atestado pelos baixos resultados obtidos no teste PISA ${ }^{23}$, em 2000 (Ciola 2008). O teste revelou que os alemães com 15 anos obtiveram os piores resultados em leitura e matemática quando comparados com outros 32 países da OECD. Há principalmente indícios de que o sistema encontra-se defasado. Durante muito tempo, a Alemanha destacou-se pela potencialidade do seu sistema dual de treinamento vocacional. Nesse sistema, parte dos adolescentes era encaminhada muito cedo para um programa de três anos que combinava aulas teóricas e experiências nas empresas. O resultado era a formação de uma mão de obra preparada em vários ofícios, o que contribuía para o relativamente baixo desemprego entre os jovens, para menores disparidades salariais entre indivíduos com e sem formação universitária e para o bom desempenho exportador. No entanto, esse sistema vem passando por dificuldades. As firmas têm reduzido o número de vagas e muitos aplicantes não conseguem emprego, sendo conduzidos para uma formação complementar e encontrando dificuldades para inserir-se no mercado de trabalho. Além disso, argumenta-se que o sistema dual, concebido há 200 anos, é rígido e inadequado para formar o trabalhador necessário nos dias de hoje (Older and Wiser 2010). Em face da nova realidade, seria necessária uma formação menos específica, capaz de preparar o indivíduo para enfrentar as flutuações do mercado de trabalho ${ }^{24}$.

Gráfico 3 - Alemanha. Indústria: Valor Agregado (\% do PIB)

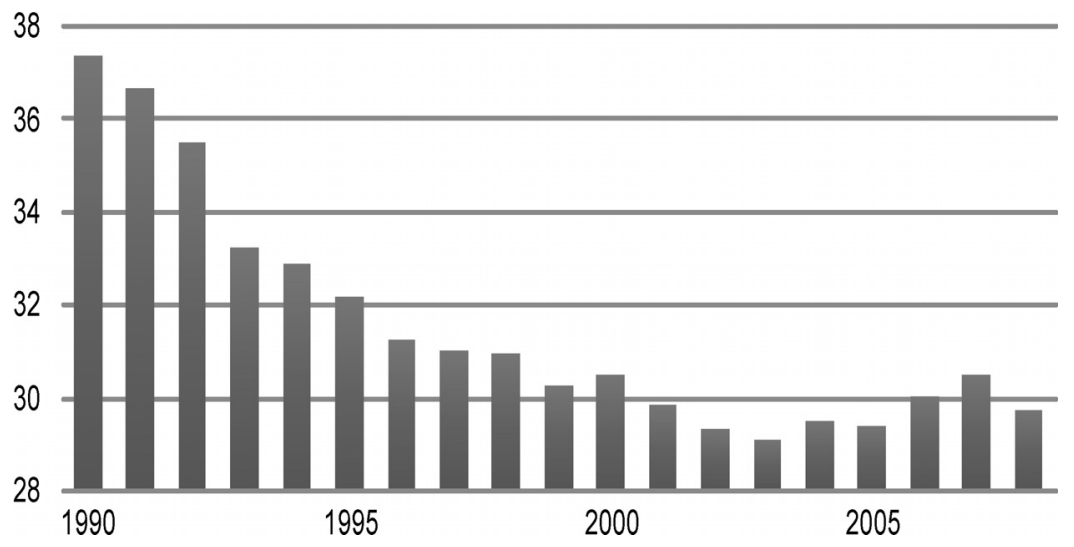

Fonte: Trading Economics (2013). 
25 Alguns aspectos relativos à crise dos países da zona do euro foram tratados na seção 3 .

26 Apesar de ser uma tendência mundial, salientam-se os efeitos negativos sobre o emprego.
Outra crítica diz respeito à forma como as crianças são encaminhadas, muito cedo, para determinado tipo de formação educacional, de acordo com o desempenho nos primeiros anos de escola. As opções são o ensino dual/vocacional, o sistema transitório, que em geral abriga as crianças com maiores dificuldades, incluindo os imigrantes, e o gynmasium, que abre caminho para a formação universitária. O problema desse sistema é que tende a reproduzir a situação dos pais, consolidando um quadro de segmentação social e contribuindo para o baixo grau de mobilidade social. É algo muito bem ilustrado pelos resultados do teste PISA, em que a Alemanha registra as maiores disparidades entre os piores e os melhores alunos (Ciola 2008, p. 82). O mesmo resultado é destacado pela The Economist (Older and Wiser 2010), que enfatiza que a Alemanha, apesar de ter boa distribuição de renda, é uma sociedade rígida, em que as oportunidades de ascensão não estão bem distribuídas. Os resultados dos adolescentes nos testes estão muito correlacionados com a posição social da família e um estudante com pais universitários tem quatro vezes mais chances de chegar à universidade. Por todas essas razões, são fortes as pressões para a reestruturação do sistema educacional na direção de ampliar os anos de estudo, fortalecer a formação das crianças em dificuldades e promover maior mobilidade educacional. São significativas, no entanto, as forças de resistência, principalmente por parte dos pais das crianças que seguem a formação de melhor qualidade.

Portanto, esses seriam os problemas relacionados à capacidade de inovação, ao grau de empreendedorismo e ao sistema educacional. Uma questão relevante é até que ponto essas dificuldades podem comprometer o desempenho exportador e a capacidade das firmas alemãs responderem às novas demandas mundiais e aos desafios de novos competidores, sobretudo os chineses. Trata-se de um ponto muito sensível, principalmente em face da dependência da economia alemã de suas exportações.

Outro conjunto de desafios está ligado à dependência alemã à economia europeia, que se defronta com os impactos da crise financeira e com o baixo crescimento econômico. Se a formação do bloco europeu contribuiu substancialmente para a elevação das exportações a partir da década de 1990, o cenário atual não se apresenta favorável. As dificuldades incluem as pressões para que a Alemanha reduza o superávit comercial, expandindo a sua política fiscal. Outro desafio diz respeito às dívidas públicas de vários países, que vêm pressionando por recursos alemães ${ }^{25}$. No final de 2011, os países europeus avançaram nas negociações para determinar metas de coordenação para a política fiscal, o que é visto como uma solução para equacionar certas dificuldades da zona do euro.

Enfim, outro ponto relaciona-se ao acirramento da concorrência e à pressão por reduzir os custos, o que vem levando empresas alemãs a transferirem parte da produção industrial para países do Leste Europeu. Essa estratégia tem, como efeito negativo, a redução do valor agregado e o menor potencial para a geração de emprego (Gráfico 3). Assim, as empresas alemãs estão usando um percentual menor de peças e componentes nacionais, implicando a redução da relação valor agregado/exportações líquidas do setor industrial, que teria reduzido de 6,7, em 1991, para 4,3 em 2002 (Raimundo 2009) ${ }^{26}$.

A alternativa mais recente é fazer dos países emergentes (Brasil, China e Índia) o foco das exportações, dando estímulos às pequenas e médias empresas. São mercados em expansão, com maior potencial para absorver as exportações alemãs. Um bom exemplo é o comércio com a China, dado que as exportações alemãs passaram de US\$ 7,2 bilhões, em 1996, para US\$ 34,9 bilhões em 2006. No entanto, o problema é que a China pode transformar-se em um futuro competidor. No presente, há grande diferença nos setores em que cada país atua e nos produtos vendidos. Contudo, essa diferença pode cair rapidamente em decorrência do progresso chinês em setores mais elaborados tecnologicamente. 
Há inclusive indícios de que as exportações chinesas para países desenvolvidos, como França, Reino Unido, Itália e Estados Unidos, vêm tirando mercado das alemãs, uma vez que as vendas para esses mercados vêm crescendo menos do que o esperado. Essa relação entre Alemanha e China é particularmente importante, tendendo muito a dizer sobre as potencialidades e os desafios do modelo de capitalismo coordenado.

\section{VII - Conclusões}

Apesar das transformações na economia internacional e das pressões crescentes, a Alemanha vem preservando traços do seu modelo de capitalismo, incluindo uma fonte de capital paciente, uma estrutura de governança corporativa baseada nos stakeholders e relações de trabalho participativas. Em um mundo em que os direitos trabalhistas vêm sendo amplamente reduzidos, a situação alemã, que inclui a participação dos trabalhadores nas decisões e a preservação dos direitos, constitui uma importante exceção. O caso alemão mostra não apenas que a preservação dessas relações é possível, mas que podem desempenhar um papel no aumento da competitividade e das exportações. Trata-se de uma boa notícia para os trabalhadores e de importante conclusão no estudo da economia política comparada.

No entanto, a Alemanha vem sofrendo muitos desafios, ligados às especificidades do seu sistema de inovação, à baixa capacidade de estimular o empreendedorismo e a problemas no sistema educacional. Equacionar essas questões é fundamental para que a Alemanha preserve os traços distintivos do seu modelo. Outro ponto diz respeito ao futuro da Europa, onde a Alemanha vem jogando as principais fichas da sua política externa. No curto prazo, o socorro aos países vem drenando recursos da economia alemã. O outro lado da moeda é a capacidade de beneficiar-se desse mercado e de estabelecer relações mais próximas e com menores riscos com os países do Leste europeu.

Enfim, há o desafio da China. A Alemanha vem se beneficiando do comércio com esse país, grande comprador de máquinas e produtor de bens industrializados a baixos custos. Um ponto central diz respeito ao impacto futuro das relações comerciais entre os dois países: será a China capaz de entrar com sucesso nos nichos industriais em que a Alemanha mantém suas vantagens comparativas? Até o momento, tanto o Japão como a Alemanha vêm garantindo a liderança em seus nichos mais elaborados, mas uma eventual invasão da China pode causar grandes danos, colocando pressões muito fortes para o modelo socialmente coordenado e, muito provavelmente, motivando uma onda protecionista.

Assim, a Alemanha precisa responder. Os arranjos institucionais do seu modelo de capitalismo constituem vantagens que podem ser exploradas para produzir respostas mais coordenadas. Entretanto, há também os pontos de veto e as fontes de resistência que precisam ser superados, inclusive para que a Alemanha preserve as suas instituições. A Alemanha precisa tornar-se menos rígida, incorporando também mais incisivamente as mulheres e os imigrantes no mercado de trabalho. Para o primeiro grupo, é necessário fortalecer a construção de creches e contribuir para reduzir as desvantagens enfrentadas pelas mulheres. Para os imigrantes, é fundamental reconhecer a formação que tiveram nos países de origem e favorecer a integração na sociedade alemã. Além disso, é necessário estimular mais incisivamente o avanço do setor serviços e criar instrumentos para encorajar o empreendedorismo e fomentar os novos setores.

A Alemanha vem demonstrando bons resultados em nichos da "economia limpa", incluindo equipamentos para economizar energia e a utilização de 
materiais para tornar os automóveis mais leves. Um esforço vem sendo feito para o desenvolvimento de carros elétricos. Outras medidas incluem a redução de impostos para empresas e a adoção de isenções tributárias e linhas especiais de crédito para certos setores, principalmente aqueles que mais inovam. Um esforço vem sendo feito também para ampliar os gastos com Pesquisa e Desenvolvimento para 3\% do PIB. Assim, boas iniciativas existem. O desafio é fortalecê-las e disseminá-las, rompendo os gargalos que impedem maior agilidade e capacidade de renovação em certos setores.

Alexandre Queiroz Guimarães (alexandre.queiroz@fjp.mg.gov.br) é Doutor em Ciência Política pela University of Sheffield (Reino Unido) e Professor da Escola de Governo - Fundação João Pinheiro.

Flavio Constantino Barbosa (flavio.constantino@hotmail.com) é Mestre em Economia pela Universidade Federal de Minas Gerais (UFMG) e Professor da Pontifícia Universidade Católica de Minas Gerais (PUC Minas).

Guilherme Ottoni Costa (g.ottoni@gmail.com) é Mestrando em Economia pela Universidade Federal de Minas Gerais (UFMG).

Enrique Natalino (enrique.natalino@governo.mg.gov.br) é Mestre em Administração Pública pela Universidade Federal de Minas Gerais (UFMG) e Assessor de Relações Internacionais da Governadoria de Minas Gerais.

Paulino Oliveira Neto (paulino.oliveira@icloud.com) é bacharel em ciências econômicas pela Pontifícia Universidade Católica de Minas Gerais.

\section{Referências}

Beaud, M. 1989. História do capitalismo: de 1500 aos nossos dias. Rio de Janeiro: Brasiliense.

Ciola, A. 2008. PISA 2000 e letramento literário: um estudo comparativo entre Brasil e Alemanha. Assis. Dissertação (Mestrado em Letras). Universidade Estadual Paulista.

Feldstein, M. 2012. The Failure of the Euro: The little currency that couldn't. Foreign Affairs, 91(1), pp. 105-116.

Fleury, A.; Fleury, M.T. 2007. Internacionalização e os países emergentes. São Paulo: Atlas.

Guimarães, A. 2006. O capitalismo coordenado alemão: do boom do pós-guerra à agenda 2010. Lua Nova, 66, pp. 22-56.

Hackenthal, A.; Schmidt, R.; Tyrell, M. 2005. Banks and German Corporate Governance: On the way to a capital market-based system? Corporate Governance, 13(3), pp. 397-407.

. 2006. The Transformation of the German Financial System. Revue D'Économie Politique, 117, pp. 431-456.

Jackson, G. 2005a. The Origins of Nonliberal Corporate Governance in Germany and Japan. In: W. Streeck; K. Yamamura, eds. The Origins of Nonliberal Capitalism. Ithaca-London: Cornell University Press.

Jackson, G. 2005b. Stakeholders under Pressure: Corporate governance and labour management in Germany and Japan. Corporate governance, 13(3), pp. 419-428.

Janning, J. 2008. A Alemanha na Europa. In: ALEMANHA. Perfil da Alemanha. Berlim: Ministério das Relações Exteriores.

Katzenstein, P. 1997. United Germany in an Integrated Europe. Current History, 96, pp. 116-123.

Lapavitsas, C.;Kaltenbrunner, A.;Lindo, D.;Michell, J.;Painceira, J.P.;Pires, E.;Powell, J.;Stenfors, A.; Teles, N. 2010. Eurozone Crisis: Beggar Thyself and Thy Neighbour. Journal of Balkan and Near Eastern Studies, 12(4), pp. 321-373

Mendes, R.; Pedroti, P. 2009. Alemanha: a internacionalização recente e o papel das instituições na entrada do século XXI. In: J.C. Cardoso Júnior; L. Acioly, eds. Trajetórias recentes de desenvolvimento: estudos de experiências internacionais selecionadas. Brasília: IPEA.

Porter, M. 1993. A vantagem competitiva das nações. Rio de Janeiro: Campus.

Raimundo, L. 2009. Alemanha: mitos, fatos e desafios para o século XXI. Texto para Discussão n. 1 413. Brasília: IPEA.

Seeleib-Kaiser, M.; Fleckenstein, T. 2007. Discourse, Learning and Welfare State Change: The case of German labour market reforms. Social Policy \& Administration, 41(55), pp. 427-448.

Straubhaar, T. 2008. A Alemanha como praça econômica. In: ALEMANHA. Perfil da Alemanha. Berlim: Ministério das Relações Exteriores.

Streeck, W. 1997. German Capitalism: Does it exist? Can it survive? In: C. Crounch; W. Streeck, eds. Political Economy of Modern Capitalism. London: Sage Publications.

. 2005. Introduction: Explorations into the origins of neoliberal capitalism in Germany and Japan. In: W. Streeck; K. Yamamura, eds. The Origins of Nonliberal Capitalism. Ithaca-London: Cornell University Press. 2012. As crises do capitalismo democrático. Novos Estudos, 92, pp. 35-56.

Vitols, S. 2005a. The Origins of Bank-Based and Market-Based Financial Systems: Germany, Japan, and United States. In: W. Streeck; K. Yamamura, eds. The Origins of Nonliberal Capitalism. Ithaca-London: Cornell University Press. . 2005b. Changes in Germany's Bank-Based Financial System: Implications for corporate governance. Corporate Governance, 13(3), pp. 386-396. 


\section{Outras fontes}

Alemanha. 2013. Foreign Trade. Wiesbaden: Statistisches Bundesamt. Disponível em: https://www.destatis.de/EN/FactsFigures/Indicators/LongTermSeries/ForeignTrade/lrahl01.html?cms_gtp = 150312_list\%253D2\&https $=1$

Brasil. 2014a. Brasil Global Net. Ministério das Relações Exteriores. Disponível em: http://www.brasilglobalnet.gov.br/. Acesso em: 20 ago 2014.

Brasil. 2014b. Indicadores nacionais de ciência e tecnologia. Ministério de Ciência e Tecnologia. DISPONíVEL EM: http://www.mct.gov.br/index.php/content/view/740.html. Acesso em: 20 ago 2014.

Older and Wiser. A Special Report on Germany. 2010. The Economist, 13 Mar. Disponível em: http://www.economist.com/sites/default/files/special-reports-pdfs/15656906.pdf. Acesso em: 20 ago 2014.

Trading Economics. 2011. Germany Unemployment Rate. Disponível em: http://www.tradingeconomics.com/germany/unemployment-rate. Acesso em: 07/10/2013.

2013. Industry; Value Added (\% of GDP) in Germany. Disponível em: www.tradingeconomics.com/germany/industry-value-added-percent-of-gdp-wb-data.html. Acesso em: 20 ago 2014.

UNESCO. 1999. Statistical Tables from the 1999 Statistical Yearbook. Disponível em: http://stats.uis.unesco.org/unesco/ReportFolders/ReportFolders.aspx. Acesso em: 20 ago 2014.

unesco institute for statistics. 2014. Data Centre. Disponível em: http://stats.uis.unesco.org/unesco/ReportFolders/ReportFolders.aspx. Acesso em: 20 ago 2014.

USPTO. 2010. Patent Statistics. Disponível em: http://www.uspto.gov/. Acesso em: 20 ago 2014.

WIPO. 2010. World Intellectual Property Indicators. Disponível em: http://www.wipo.int/export/sites/www/freepublications/en/intproperty/941/wipo_pub_941_2010.pdf.Acesso em: 20 ago 2014.

The World Bank. 2013. Scientific and Technical Journal Articles. Washington, D.C.: The World Bank Group.

\section{ABSTRACT}

The Federal Republic of Germany consolidated, in the twentieth century, a very specific model of capitalism, marked by a structure of corporate governance centred on the stakeholders, by participative labour relations and by a patient source of capital, fruit of the close relationships developed between the banks and the enterprises. These factors contributed to explain critical features of the model, including the sources of comparative advantage, the pattern of innovation and the low inequality in wages. Nevertheless, the model suffered pressures on the 1970s, results of the changes in international capitalism. The objective of the article is to evaluate the evolution of the German model in response to those challenges. A central issue is to investigate how the institutions have evolved and in which sense Germany still has a specific model of capitalism. Another point is to understand the challenges faced in terms of productivity and competitiviness, relating them to the institutional features, to the international context and to German foreign strategy. The article employs the approachs historical institutionalism and models of capitalism, approachs which explore the institutional characteristics of the countries and their resilience. It utilises bibliographical sources, press artices related to economics and international politics and data source which dialogue with the institutional aspects of the German economy. As the main conclusions, the article argues that the German model has been transformed, but critical institutional features have been preserved, playing an essential role in the success of the economy. The results indicate that a different model of capitalism, more participative and democratic, is still possible, despite the new configurations of capitalism. The article emphasises the role of the participative practices and of the workers' cooperation for the positive results achieved by the model. The article also illuminates the challenges which have to be faced by the German economy.

KEYWORDS: Germany; coordinated capitalism; historical institutionalism; political economy; models of capitalism. 